Article

\title{
Farmers' Perception of Good Agricultural Practices in Rice Production in Myanmar: A Case Study of Myaungmya District, Ayeyarwady Region
}

\author{
Soe Paing Oo ${ }^{1,2, *(1)}$ and Koichi Usami ${ }^{1}$ \\ 1 Graduate School of International Development (GSID), Nagoya University, Nagoya 464-8601, Japan; \\ usami@gsid.nagoya-u.ac.jp \\ 2 Department of Agronomy, Yezin Agricultural University (YAU), Nay Pyi Taw 15013, Myanmar \\ * Correspondence: soe.paing.oo@b.mbox.nagoya-u.ac.jp or soepaingo@gmail.com; Tel.: +81-90-4245-2575
}

Received: 22 May 2020; Accepted: 25 June 2020; Published: 27 June 2020

\begin{abstract}
Although the Myanmar Ministry of Agriculture and Irrigation (MOAI) implemented Good Agricultural Practices (GAPs) in rice production, farmers' application of GAPs is decreasing. This study was conducted to examine farmers' perception of GAPs and the determinants of that perception. Data were collected using a structured questionnaire from a random selection of 315 farmers. By applying principal component analysis (PCA) and cluster analysis, the study found that all component technologies of GAPs have relative advantages and visible benefits. However, these component technologies of GAPs in rice production are perceived as relatively difficult to apply by farmers. According to the result of the binary logit model, determinants of farmers' perception were gender, education, farmland size, access to credit, income from crop production, contact with extension agents, receiving agricultural information, and receiving training in GAPs in rice production. Some agricultural policies and extension activities are needed to enhance farmers' perceptions of the compatibility of GAPs in rice production. First, the implementation of GAPs in rice production should focus mainly on low-income farmers who own small amounts of farmland. Second, MOAI should reform the credit plan for farmers who wish to accept GAPs in rice production. Third, extension workers should have regular contact with farmers to enhance farmers' perception of the compatibility of GAPs in rice production. Finally, more agricultural information should be provided, especially for farmers who have larger farms and higher income, concerning the advantages of using GAPs in rice production.
\end{abstract}

Keywords: perception; GAPs; adoption; binary logit model; Myanmar

\section{Introduction}

Myanmar's national average rice yield in 2013 was the second-lowest in Asia [1], despite the introduction of Good Agricultural Practices (GAPs) in rice production in 2008 by the Ministry of Agriculture and Irrigation (MOAI) as a nationwide program to enhance the country's rice yield. According to the results of previous studies [2-4], the implementation of GAPs in rice production by MOAI resulted in an increase in Myanmar's rice yield [5-7]. Results of a field experiment showed that the rice yield under GAPs (4.28 $\mathrm{t} / \mathrm{ha}$ ) was higher than that under the conventional method (3.10 $\mathrm{t} / \mathrm{ha})$ [8]. GAPs in rice production comprised a package of technologies, including improved variety, nursery preparation and intensive care, transplanting, weeding and pest management, nutrient management, water management, and timely and proper harvesting [9]. These technologies are understood to be suited for a particular environment and aim at helping farmers to boost the yield of rice [10]. GAPs is a voluntary codified system that is related to the efficient production of crops and aims towards 
sustainability and equity for small-scale farmers [11-15]. The benefits of using GAPs in rice production are shown in Table 1, which shows the rice yield of rice is directly related to five component technologies (GAP1, GAP4, GAP5, GAP6, and GAP9). If farmers adopt these five component technologies, yield components, such as number of tillers, number of panicles, number of spikelets, and thousand-grain weight, will be increased and rice yield will be enhanced.

Table 1. Good Agricultural Practices (GAPs) components and benefits in rice production.

\begin{tabular}{cc}
\hline Components & Benefits \\
\hline GAP1(Quality seeds) & Seed rate will be reduced, and robust seedlings are produced. \\
\hline GAP2(Sparse sowing) & Sparse sowing will provide uniform growth of seedlings. \\
\hline GAP3(Covering) & Covering will conserve moisture and easy for uprooting. \\
\hline GAP4(Systematic care of nursery) & Healthy and vigorous seedlings will be provided by systematic care of \\
the nursery.
\end{tabular}

The characteristics of GAPs in rice production are related to not only increasing rice yield but also improving environmental benefits. GAPs in rice production enhance the production of safe and good quality food. These practices are usually environmentally safe and ensure that the final product is appropriately handled, stored, and transported. The adoption of GAPs in rice production helps to promote sustainable agriculture [17]. GAPs in rice production also provide safety products with a safe environment. Higher revenue will be generated by the use of GAPs in rice production [18]. Protection of crops against pests, diseases, and weeds must be achieved using appropriate control measures. If growers adopt GAPs in rice production, pest control actions have no potential impact on workers, food, and environmental and health safety. Although MOAI implemented GAPs in rice production, the adoption rate of farmers in 2016 remained at a low level: $16.57 \%$ in terms of area cultivated [19].

In adoption studies, farmers' decisions to adopt a new technology depend on many complex factors. One such factor is farmers' perception of the characteristics of the new agricultural technology [20-22]. Farmers' perception of agricultural technology influences their decision on adopt that technology [22]. Furthermore, farmer behavior is determined by their perception of sustainable agriculture [23]. It is likely that the successful adoption of conservation practices would be more influenced by the farmers' attitude and perception than any other factors [24]. When adopting technologies, farmers must pass the stage of evaluating them as a part of the adoption process. Farmers' prior experience in using technologies is likely to affect their perception of new technology $[25,26]$. If farmers properly receive information about new technologies, they will adopt those technologies quickly. Therefore, it is thought that one of the reasons for the low adoption of GAPs in rice production in Myanmar may be the low 
perception of farmers, although farmers' perception of agricultural technologies varies from household to household because of different interactive factors [27].

Technology characteristics are one of the major driving forces of farmers' adoption decisions [28]. Farmers' perceptions and characteristics are influential in the preliminary step of extension programs to promote sustainability of adoption among farmers [29]. A better understanding of farmers' perception of technologies and its impact on technology adoption will provide valuable information to technology providers [30]. Five characteristics (relative advantage, compatibility, complexity, trialability, and observability) of new technologies or products influence the adoption of these technologies or products [31]. Farmers' perception of the compatibility of sustainable practices with their farming systems is the best predictor of the adoption of such practices [32]. Indeed, an individual's perception of these five characteristics predicts the rate of adoption of new technologies [33].

Therefore, the present study aims at (i) clarifying farmers' perception of GAPs in rice production and (ii) examining determinants of farmers' perception of GAPs in rice production.

\section{Materials and Methods}

\subsection{Framework and Variables}

Researchers define perception in a variety of ways. Perception is defined as an interpretation of information [34]. Perception is mentioned as a process through which a person receives information or stimuli from the environment and transforms it into psychological awareness [35]. Farmers' perception is the knowledge and behavior of farmers regarding something [36]. Perception is mentioned as a cognitive process where an individual gives meaning to the environment [37]. In this study, perception is defined as an understanding of the characteristics of GAPs in rice production. Herein, these characteristics of GAPs in rice production are relative advantages, compatibility, complexity, trialability, and observability. These five characteristics of technology play a crucial role in farmers' decision making on adopting a given technology [38]. Therefore, since GAPs in rice production consist of 14 component technologies, the perception of GAPs in rice production is measured by 70 variables ( 5 characteristics $\times 14$ component technologies).

There is a significant association between perceptions of selected sustainable agricultural technologies and characteristics, such as the age of the farmer, education, farming experience, farmland size, and contact with the information source [21]. Farmers' characteristics, such as age, education, land area, and number of family members, have a positive influence on farmers' perception [36]. Age, sex, education level, and farming experience have been adopted as explanatory variables for analysis of farmers' perception of an agricultural information resource center [39]. Moreover, age and cultivation area significantly were found to influence current perceptions of GAPs in a study of coffee farmers [40]. Farmers' perception of soil and water conservation practices in Ethiopia is influenced by age and education of farmers, farmers' previous experience in soil and water conservation, contact with extension agents, and participation in soil and water conservation training [41]. Explanatory variables such as age, gender, and education of the farmer, farming experience, household size, farm income, extension services, and access to credit were used to analyze farmers' perceptions of and adaptation to the effects of climate change in Kenya [42]. Characteristics such as age of the farmer, gender, education, marital status, member group, family members, family labor, farm size, and farming experience were shown to be determinants of farmers' perceptions towards the economic sustainability of rice farming [43]. Age and education level, number of the household labor force, farm income, and extension visits significantly contribute to farmers' perception of organic vegetable production [44]. Farmers' characteristics, such as age, education level of the farmer, and household size affect coping strategies in the perception of rice farmers in Tanzania [45]. Variables such as education, farming experience, and special training or extension programs have also been found to be determinants of farmers' perception toward production constraints [46]. 
In the present study, farmers' perception of GAPs in rice production is assumed to be influenced by two main factors: internal factors (personal characteristics, farming characteristics, and economic characteristics) and external factors (institutional characteristics) (Figure 1).

Internal Factor

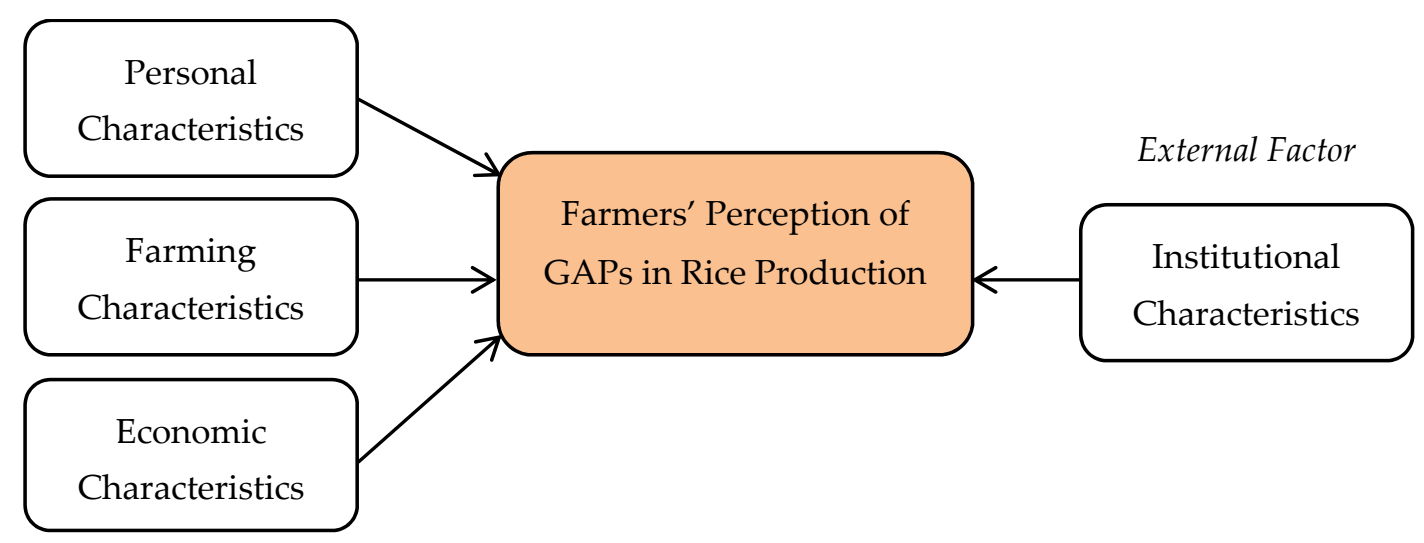

Figure 1. Conceptual framework of the study.

The present study takes the age, gender, marital status, education, and farming experience of the household head, and household size as personal characteristics (Table 2).

Table 2. List of internal and external factors.

\begin{tabular}{|c|c|c|}
\hline Variables & Description & Sign \\
\hline \multicolumn{3}{|l|}{ Personal characteristics } \\
\hline Age & Age of household head & AGE \\
\hline Gender & 1 for male; 0 otherwise & GEN \\
\hline Marital status & 1 for married; 0 otherwise & MST \\
\hline Education & Years of formal schooling & EDU \\
\hline Farming experience & $\begin{array}{l}\text { Years of farming experience of household head in } \\
\text { the rice field }\end{array}$ & FEXP \\
\hline Household size & Number of household members (persons) & HHSIZE \\
\hline \multicolumn{3}{|l|}{ Farming characteristics } \\
\hline Farmland size & Size of farmland owned by household (hectares) & FSIZE \\
\hline Active labor force & $\begin{array}{l}\text { Number of household members actively involved } \\
\text { in crop production (persons) }\end{array}$ & LAB \\
\hline \multicolumn{3}{|l|}{ Economic Characteristics } \\
\hline Access to credit & $\begin{array}{c}1 \text { if household head has access to credit; } 0 \text { otherwise } \\
\text { Level of annual household income from crop } \\
\text { production: }\end{array}$ & CRE \\
\hline Income from crop production & 1 for low $(<6,000,000$ kyats $)$ & INC \\
\hline & 2 for medium $(6,000,000-10,000,000$ kyats $)$ & \\
\hline & 3 for high $(>10,000,000$ kyats $)$ & \\
\hline \multicolumn{3}{|l|}{ Institutional characteristics } \\
\hline Contact with extension workers & Number of meetings per year in 2017 (times) & EXT \\
\hline Receiving agricultural information & 1 for received; 0 otherwise & INF \\
\hline Receiving GAPs in rice production training & 1 for received; 0 otherwise & RGAP \\
\hline Membership in local farmers' association & 1 for member; 0 otherwise & MLFA \\
\hline Membership in seed growers' association & 1 for member; 0 otherwise & MSGA \\
\hline
\end{tabular}

Farmland size and active labor force account for farming characteristics. Access to credit and income from crop production are included as economic characteristics. Institutional characteristics comprise contact with extension agents, receiving agricultural information, receiving GAPs in rice production training, membership in local farmers' association, and membership in seed growers' association. 


\subsection{Study Area and Sampling}

Ayeyarwady Region is the most well-known region in Myanmar due to its large rice cultivation area. Myaungmya District, in the Ayeyarwady Region, was selected as the study area. Among the six districts in Ayeyarwady (Myaungmya, Pathein, Hinthada, Maubin, Pyapon, and Labutta), Myaungmya represents the Ayeyarwady Region in terms of two criteria. First, the mean yield of rice in the district was $3.21 \mathrm{t} /$ ha, nearly the same as the $3.46 \mathrm{t} / \mathrm{ha}$ of Ayeyarwady Region. Second, the number of GAPs in rice production training in the district was 12, slightly lower than the 14.17 of the Ayeyarwady Region [47]. Since Myaungmya District consists of three townships-Myaungmya, Einme, and Warkhema-all townships were included in the study area (Figure 2). Nine villages ( 3 villages $\times 3$ townships) were randomly selected, and 35 farmers from each village were chosen by landholding size. Therefore, the total sample for this study was 315 farm households.

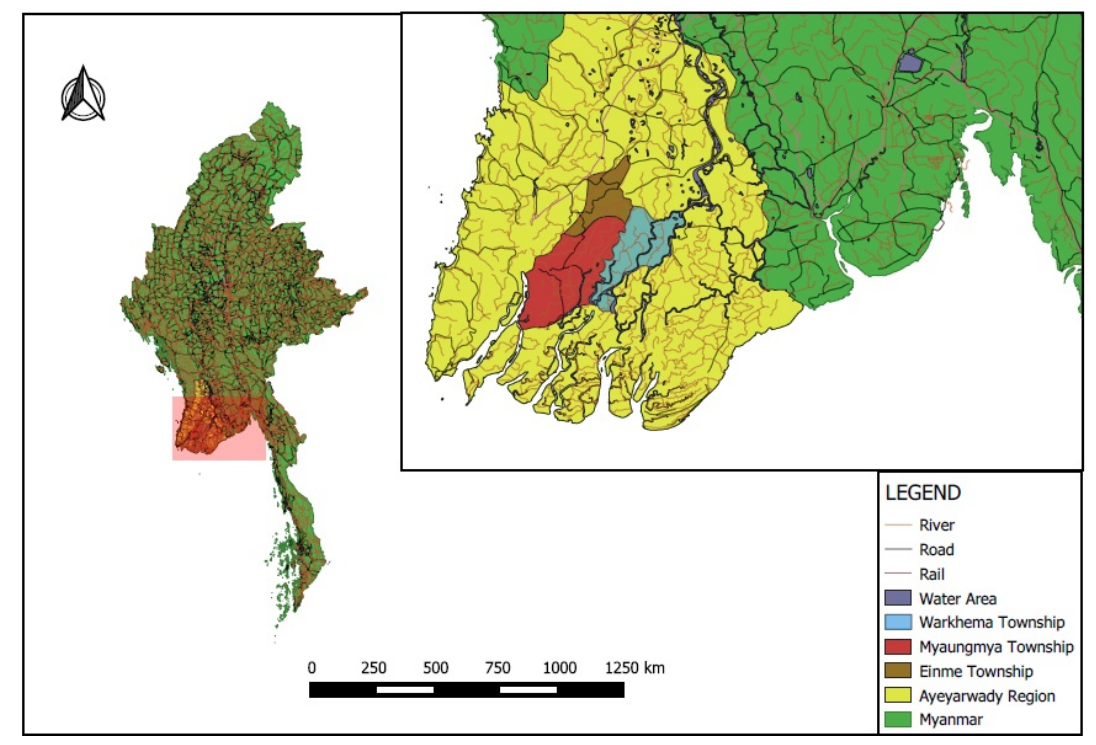

Figure 2. The map of the study area. Source: [48].

\subsection{Data Measurement}

According to the results of a pilot survey and key informant interviews, structured questionnaires were conducted by face-to-face interviews. The five characteristics of component technologies-relative advantage, compatibility, complexity, trialability, and observability-were used to measure farmers' perception of GAPs in rice production. These five characteristics are essential in studying technology adoption and play a crucial role in farmers' decision making [38]. Therefore, the questionnaire for farmers' perception included seventy statements (5 characteristics $\times 14$ component technologies). For example, all statements for GAP1 are shown in Table 3.

Table 3. Statements to measure the characteristics of GAP1 (Quality seeds).

\begin{tabular}{cr}
\hline Characteristics & Statements \\
\hline Relative advantage & The higher yield can be expected by using quality seeds. \\
Compatibility & It is compatible to use quality seeds for farmer. \\
Complexity & It is difficult for farmers to use quality seeds. \\
Trialability & You can test the characteristics of quality seeds. \\
Observability & You have a chance to observe the benefit of using quality seeds. \\
\hline
\end{tabular}

The respondents were requested to indicate the extent of their agreement with each statement using a Likert-scale five-point continuum: strongly disagree, disagree, neither agree nor disagree, agree, and strongly agree with assigned scores of 1, 2, 3, 4, and 5, respectively [23,39,49-53]. Then, 
based on the score, respondents were categorized into two types: if the score was less than 4, they did "not perceive," while if the score was equal to or greater than 4 , they did "perceive" $[49,53]$. Cronbach's alpha was calculated to examine the reliability of data collected on farmers' perception of GAPs in rice production.

\subsection{Data Analysis}

A descriptive analysis using average, standard deviation, percentage, variance, and a comparison was carried out to clarify the primary features of farmers' perception of GAPs in rice production. Furthermore, farmers were categorized based on their perception of GAPs in rice production through principal component analysis (PCA) and cluster analysis. The former analysis enabled reducing the number of perception variables to several principal components to describe the features of perception of GAPs in rice production for each cluster that could be derived from the later analysis.

Assuming that the dependent variable $\left(Y_{i}\right)$ is "perceive" or "not perceive," the binary logit model to examine the determinants of farmers" perception of GAPs in rice production is as follows $[35,54,55]$ :

$$
Y_{i}=\left\{\begin{array}{c}
1 \text { (perceive) } \\
0 \text { (not perceive) }
\end{array}\right.
$$

supposing: $P_{i}=$ Probability of perceive and and $1-P_{i}=$ Probability of not perceive:

$$
\begin{gathered}
P_{i}=\frac{1}{1+e^{-Z i}} \\
1-P_{i}=\frac{1}{1+e^{Z i}}
\end{gathered}
$$

According to [56],

$$
\begin{gathered}
\frac{P_{i}}{1-P_{i}}=e^{\beta_{i} X_{i}+u_{i}} \\
l_{n}\left(\frac{P_{i}}{1-P_{i}}\right)=\beta_{i} X_{i}+u_{i}, i=1,2,3, \ldots, n
\end{gathered}
$$

where $X_{i}$ is the set of independent variables, $\beta_{i}$ is the coefficient of independent variables, and $u_{i}$ is an error term. The present study employed the following equation:

$$
\begin{aligned}
\ln \left(\frac{P_{i}}{1-P_{i}}\right)= & \beta_{0}+\beta_{1} A G E+\beta_{2} G E N+\beta_{3} M S T+\beta_{4} E D U+\beta_{5} F E X P+\beta_{6} H H S I Z E+ \\
& \beta_{7} F S I Z E+\beta_{8} L A B+\beta_{9} C R E+\beta_{10} I N C+\beta_{11} E X T+\beta_{12} I N F+ \\
& \beta_{13} R G A P+\beta_{14} M L F A+\beta_{15} M S G A+u_{i}
\end{aligned}
$$

\section{Results and Discussion}

\subsection{Farmers' Characteristics}

The characteristics of respondents (farmers) are summarized in Table 4. Some farmers' characteristics were collected in conjunction with a sample the authors analyzed in a previous study [48]. The mean age of farmers was 50.25 years. Most were male and married. Their mean value of education was 5.57 years. On average, farmers managed 3.92 hectares of farmland, and had 25.56 years of farming experience. The mean household size was 4.51 persons, and the average number of the active labor force was 3.39 persons.

The mean income from total crop production per year was 8,004,010 kyats (USD 5674). They received agricultural information and could access credit for rice production. The average number of contacts with extension agents was 2.87 times in 2017. Around half of the respondents were members of the local farmers' association. Only 7.9 percent of farmers were involved in a seed growers' association. 
Table 4. Descriptive summary of farmers' characteristics.

\begin{tabular}{ccc}
\hline \multirow{2}{*}{ Farmers' Characteristics } & \multicolumn{2}{c}{ Number of Farmers = 315 } \\
\cline { 2 - 3 } & Mean & Standard Deviation \\
\hline Age (years) & 50.25 & 12.576 \\
Gender (\% of male) & 97.46 & 15.8 \\
Marital status (\% of married) & 95.24 & 21.3 \\
Education (years) & 5.57 & 3.309 \\
Farming experience (years) & 25.56 & 13.706 \\
Household size (persons) & 4.51 & 1.607 \\
\hline Farmland size (hectares) & 3.92 & 5.42 \\
Active labor force (persons) & 3.39 & 1.427 \\
\hline Access to credit (\%) & 91.74 & 27.6 \\
Income from crop production (*kyats/year) & $8,004,010$ & $11,244,539$ \\
\hline Contact with extension workers (times) & 2.87 & 3.658 \\
Receiving agricultural information (\%) & 87.94 & 32.6 \\
Receiving GAPs in rice production training (\%) & 27 & 44.46 \\
Membership in local farmers' association (\%) & 45.71 & 49.9 \\
Membership in seed growers' association (\%) & 7.9 & 27.07 \\
\hline
\end{tabular}

Source: Authors and [48]. Note: ${ }^{*}=$ Kyat is the currency of Myanmar; 1 kyat $=0.00071$ USD or 1 USD $=1408.25$ kyats as of 1 May 2020.

\subsection{Farmers' Perception of GAPs in Rice Production}

Farmers' perception of GAPs in rice production is shown in Table 5. Since the value of Cronbach's alpha for data on farmers' perception was 0.894 (i.e., greater than 0.7), the data were considered reliable for the analysis. Hereafter, perception is defined as follows: (a) perceive $=$ scores of 4 and 5, (b) not perceive $=$ scores of 1,2 , and 3 .

Table 5. Distribution of farmers who perceive and do not perceive the statement of GAPs in rice production.

\begin{tabular}{|c|c|c|c|c|c|c|c|c|c|c|c|c|c|c|c|}
\hline \multirow{3}{*}{$\begin{array}{l}\text { Components } \\
\text { of GAPs in } \\
\text { Rice } \\
\text { Production }\end{array}$} & \multicolumn{3}{|c|}{$\begin{array}{c}\text { Relative } \\
\text { Advantage }\end{array}$} & \multicolumn{3}{|c|}{ Compatibility } & \multicolumn{3}{|c|}{ Complexity } & \multicolumn{3}{|c|}{ Trialability } & \multicolumn{3}{|c|}{ Observability } \\
\hline & \multicolumn{2}{|c|}{$\begin{array}{l}\text { Percentage } \\
\text { of Farmers }\end{array}$} & \multirow[t]{2}{*}{$\overline{\mathbf{X}}$} & \multicolumn{2}{|c|}{$\begin{array}{l}\text { Percentage } \\
\text { of Farmers }\end{array}$} & \multirow[t]{2}{*}{$\overline{\mathbf{X}}$} & \multicolumn{2}{|c|}{$\begin{array}{l}\text { Percentage } \\
\text { of Farmers }\end{array}$} & \multirow[t]{2}{*}{$\bar{X}$} & \multicolumn{2}{|c|}{$\begin{array}{l}\text { Percentage } \\
\text { of Farmers }\end{array}$} & \multirow[t]{2}{*}{$\bar{X}$} & \multicolumn{2}{|c|}{$\begin{array}{l}\text { Percentage } \\
\text { of Farmers }\end{array}$} & \multirow[t]{2}{*}{$\bar{x}$} \\
\hline & $\mathbf{a}$ & b & & $\mathbf{a}$ & b & & $\mathbf{a}$ & $\mathbf{b}$ & & a & b & & $\mathbf{a}$ & $\mathbf{b}$ & \\
\hline GAP1 & 98 & 2 & 4.8 & 87 & 13 & 4.3 & 80 & 20 & 4.1 & 72 & 28 & 3.9 & 77 & 23 & 4 \\
\hline GAP2 & 96 & 4 & 4.7 & 59 & 41 & 3.5 & 80 & 20 & 4 & 94 & 6 & 4.5 & 95 & 5 & 4.5 \\
\hline GAP3 & 97 & 3 & 4.7 & 55 & 45 & 3.3 & 79 & 21 & 4 & 71 & 29 & 3.9 & 81 & 9 & 4.5 \\
\hline GAP4 & 100 & 0 & 4.9 & 61 & 39 & 3.6 & 74 & 26 & 3.8 & 80 & 20 & 4.1 & 93 & 7 & 4.5 \\
\hline GAP5 & 97 & 3 & 4.7 & 50 & 50 & 3.3 & 79 & 21 & 4 & 76 & 24 & 4 & 75 & 25 & 3.9 \\
\hline GAP6 & 96 & 4 & 4.8 & 35 & 65 & 2.8 & 79 & 21 & 4 & 72 & 28 & 3.7 & 70 & 30 & 3.7 \\
\hline GAP7 & 95 & 5 & 4.7 & 75 & 25 & 4 & 76 & 24 & 3.9 & 72 & 28 & 3.9 & 81 & 19 & 4.1 \\
\hline GAP8 & 99 & 1 & 4.8 & 52 & 48 & 3.4 & 70 & 30 & 3.7 & 73 & 27 & 3.9 & 71 & 29 & 3.7 \\
\hline GAP9 & 89 & 11 & 4.4 & 37 & 63 & 2.9 & 90 & 10 & 4.3 & 71 & 29 & 3.7 & 71 & 29 & 3.7 \\
\hline GAP10 & 93 & 7 & 4.6 & 80 & 20 & 4.1 & 91 & 9 & 4.3 & 72 & 28 & 3.9 & 89 & 11 & 4.3 \\
\hline GAP11 & 98 & 2 & 4.8 & 54 & 46 & 3.5 & 86 & 14 & 4.2 & 94 & 6 & 4.4 & 70 & 30 & 3.7 \\
\hline GAP12 & 87 & 13 & 4.3 & 81 & 19 & 4.1 & 85 & 15 & 4.1 & 74 & 26 & 3.9 & 89 & 11 & 4.3 \\
\hline GAP13 & 97 & 3 & 4.8 & 58 & 42 & 3.5 & 77 & 23 & 3.9 & 63 & 37 & 3.5 & 83 & 17 & 4.3 \\
\hline GAP14 & 77 & 23 & 4.1 & 56 & 44 & 3.4 & 72 & 28 & 3.7 & 94 & 6 & 4.4 & 92 & 8 & 4.4 \\
\hline
\end{tabular}

Note: (1) a = Percentage of farmers who perceive the characteristic, $b=$ Percentage of farmers who do not perceive the characteristic, and $\bar{X}=$ mean of scores. (2) GAP1 = Quality seeds, GAP2 = Sparse sowing, GAP3 = Covering, GAP4 = Systematic care of nursery, GAP5 = Uprooting \& transplanting, GAP6 = Planting depth, GAP7 = Seedlings per hill, GAP8 = Plant population, GAP9 = Alternate wetting \& drying, GAP10 = Pests \& disease management, GAP11 $=$ Balanced inputs, GAP12 = Submerging, GAP13 = Drainage, and GAP14 = Combine harvester. 


\subsubsection{Relative Advantage}

Most farmers perceived that all component technologies of GAPs in rice production have a relative advantage since the mean of the score $(\bar{X})$ was more than 3.5. Among the 14 component technologies of GAPs in rice production, the means of the scores for GAP9 (Alternative wetting and drying), GAP12 (Submerging), and GAP14 (Combine harvester) were comparatively low compared with those of the other component technologies of GAPs in rice production.

\subsubsection{Compatibility}

Because the mean of their scores was more than 3.5, GAP1 (Quality seeds), GAP4 (Systematic care of nursery), GAP7 (Seedlings per hill), GAP10 (Pests and disease management), and GAP12 (Submerging) were perceived to be compatible with their current farming practices. In contrast, farmers' perception on compatibility was low in six component technologies of GAPs in rice production: GAP3 (Covering), GAP5 (Uprooting and transplanting), GAP6 (Planting depth), GAP8 (Plant population), GAP9 (Alternate wetting and drying), and GAP14 (Combine harvester). It is of interest that there was a difference in the variance among the 14 component technologies.

\subsubsection{Complexity}

Since the mean of their scores was more than 3.5, most of the farmers perceived that all component technologies of GAPs in rice production have complexity. Among 14 component technologies of GAPs in rice production, relating to the percentage of farmers who perceive complexity, the highest was around 90\% for GAP9 (Alternative wetting and drying) and GAP10 (Pests and disease management), while the lowest was around 70\% for GAP8 (Plant population) and GAP14 (Combine harvester).

\subsubsection{Trialability}

Because the mean of their scores was more than 3.5, with the exception of GAP13 (Drainage), farmers perceived that almost all component technologies of GAPs in rice production could be easily tried on their farm. For GAP13 (Drainage), although its score was not low, 63\% of farmers perceived its trialability.

\subsubsection{Observability}

Most farmers perceived that all component technologies of GAPs in rice production have observability since the mean was more than 3.5. Among 14 component technologies of GAPs in rice production, the highest percentage $(95 \%)$ of farmers who perceived observability, was seen for GAP2 (Sparse sowing), while a comparatively low percentage (70-71\%) of farmers perceived observability for GAP6 (Planting depth), GAP8 (Plant population), GAP9 (Alternate wetting and drying), and GAP11 (Balanced inputs).

\subsubsection{Perception as a Whole}

Farmers perceived that all component technologies of GAPs in rice production have three characteristics: relative advantages, complexity, and observability. Among 14 components of GAPs in rice production, the comparatively higher perception on compatibility was limited to GAP1 (Quality seeds), GAP4 (Systematic care of nursery), GAP7 (Seedlings per hill), GAP10 (Pests and disease management), and GAP12 (Submerging). Regarding trialability, the comparatively lower perception was limited to only GAP13 (Drainage), although 63\% of farmers perceived it.

According to the dendrogram (Figure 3) of cluster analysis by the hierarchical clustering method, the 14 component technologies of GAPs in rice production could be classified into three groups.

Farmers' perception of GAPs in rice production for each cluster is summarized in Table 6. Five components, namely, GAP1 (Quality seeds), GAP7 (Seedlings per hill), GAP10 (Pests and disease management), GAP12 (Submerging), and GAP13 (Drainage) were observed in Cluster 1. All five 
characteristics were perceived by farmers in Cluster 1 because the mean of their scores was more than 3.5. In Cluster 2, four component technologies related to nursery management and combine harvester were involved. Transplanting operations, water, and nutriment management were classified to Cluster 3. Farmers have a low perception of compatibility for Cluster 2 and Cluster 3. All clusters have a high perception of relative advantage.

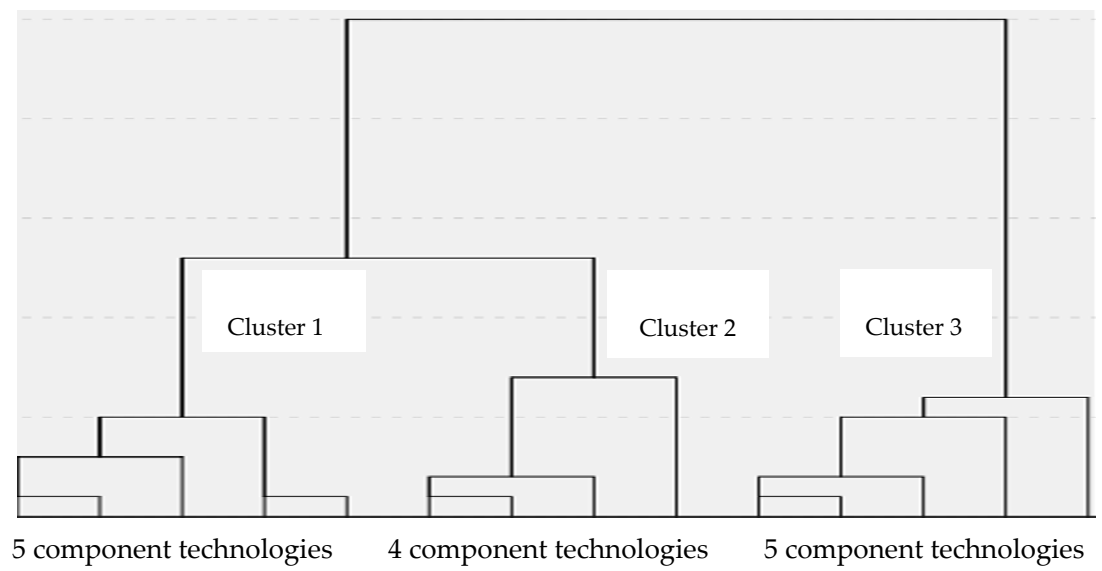

Figure 3. Dendrogram of 14 component technologies of GAPs of rice.

Table 6. The result of cluster analysis of 14 component technologies of GAPs in rice production.

\begin{tabular}{cccccccc}
\hline \multirow{2}{*}{ Cluster } & \multicolumn{2}{c}{ Component Technologies of GAPs in Rice Production } & \multicolumn{4}{c}{ Mean Value } \\
\cline { 2 - 8 } & Number & Name & RA & COM & CPLEX & TR & OBS \\
\hline 1 & 5 & GAP1, GAP7, GAP10, GAP12, and GAP13 & 4.64 & 4 & 4.06 & 3.82 & 4.2 \\
2 & 4 & GAP2, GAP3, GAP4, and GAP14 & 4.6 & 3.45 & 3.88 & 4.23 & 4.48 \\
3 & 5 & GAP5, GAP6, GAP8, GAP9, and GAP11 & 4.7 & 3.18 & 4.04 & 3.94 & 3.74 \\
\hline
\end{tabular}

Note: (1) RA = relative advantage, COM = compatibility, CPLEX = complexity, TR = trialability, and OBS = observability. (2) GAP1 = Quality seeds, GAP2 = Sparse sowing, GAP3 = Covering, GAP4 = Systematic care of nursery, GAP5 = Uprooting \& transplanting, GAP6 = Planting depth, GAP7 = Seedlings per hill, GAP8 = Plant population, GAP9 = Alternate wetting \& drying, GAP10 = Pests \& disease management, GAP11 = Balanced inputs, GAP12 $=$ Submerging, GAP13 $=$ Drainage, and GAP14 $=$ Combine harvester.

\subsection{Classification of Farmers Based on Their Perception of GAPs in Rice Production}

\subsubsection{Common Factors of Perception of GAPs in Rice Production}

Firstly, principal component analysis (PCA) was applied to reduce the number of perception variables $(5$ characteristics $\times 14$ component technologies $=70)$ to several principal components (common factors) to describe the feature of perception of GAPs in rice production. In PCA, the Kaiser-Meyer-Olkin (KMO) test was used to determine that the data was suited for the analysis. Since the value of KMO was 0.828 and Bartlett's Test of Sphericity was significant at the $1 \%$ level, the collected data were useable for PCA. The result of varimax-rotated factor analysis (Table 7) shows that there are sixteen common factors of farmers' perception of GAPs in rice production. These common factors explained $71.487 \%$ of the variance. These 16 common factors can be given a label based on the factor loading of a significant variable. Common factors of farmers' perception of GAPs in rice production are as follows.

\section{CF1: Trialability of GAPs}

The result shows that in the first common factor (CF1), 14 out of 70 variables were classified as trialability of GAPs in rice production. This means that farmers' perception of trialability of all component technologies of GAPs in rice production was considered as one common factor and explained 14.879 percent of the variance. 


\section{CF2: Advantages of GAPs (Except Submerging and Harvester)}

The second common factor (CF2) showed 6.5 percent of the variance and was named advantages of GAPs in rice production because variables involved in the perception of relative advantages of GAPs in rice production (with the exception of two components-submerging and using combine harvester) were observed in this factor.

CF3: Visible Results of Using Nursery, Pest Management, Submerging, and Harvester

In CF3, observability of five component technologies-sparse sowing (0.864), systematic care of nursery (0.822), pest and disease management (0.808), submerging (783), and combine harvester (0.774) — were observed, and it explained 7.916 percent of the variance.

CF4: Compatible with Sowing, Transplanting, Inputs, and Drainage

Common factor CF4 explained 5.125 percent of the variance with five variables, namely, compatibility of sparse sowing (0.895), compatibility of transplanting (0.61), compatibility of plant population (0.832), compatibility of balanced inputs (0.837), and compatibility of drainage (0.887).

CF5: Visible Results of Using Quality Seeds, Nursery, AWD, and Inputs

In CF5, observability of four component technologies-quality seeds (0.857), uprooting and transplanting (0.838), alternate wetting and drying (AWD) (0.829), and balanced inputs (0.811) -were reduced to one common factor, which explained 4.552 percent of the variance.

CF6: Complexity of Nursery, Population, and Harvester

CF6 explained 4.543 percent of the variance and contained three variables: systematic care of nursery (0.906), plant population (0.901), and combine harvester (0.905).

CF7: Complexity of Sowing, Planning Depth, Pest Management, and Submerging

CF7 described 4.405 percent of the variance and four variables were integrated into this factor: sparse sowing (0.826), planting depth (0.841), pests and disease management (0.711), and submerging (0.783).

CF8: Complexity of Quality Seeds, Transplanting, AWD, and Inputs

Four variables-quality seeds (0.918), uprooting and transplanting (0.903), alternate wetting and drying (AWD) (0.584), and balanced inputs (0.827)—-were observed in CF8 and explained 4.151 percent of the variance.

CF9: Compatible with Quality Seeds, Seedling Number, and Pest Management

CF9 described 4.056 percent of the variance and consisted of four variables. These were compatibility of quality seeds (0.818), compatibility of seedlings per hill (0.787), compatibility of pest and disease management (0.787), and compatibility of submerging (0.791).

CF10: Compatible with Covering, Planting Depth, AWD, and Harvester

CF10 explained 3.944 percent of the variance, and four variables were found in this factor. These were compatibility of covering (0.832), compatibility of planting depth (0.738), compatibility of alternate wetting and drying (AWD) (0.728), and compatibility of a combine harvester (0.867).

CF11: Complexity of Covering, Seedling Number, and Drainage

The result showed that 3.67 percent of the variance and three variables-soil covering (0.801), seedlings per hill (0.783) and drainage (0.798)—were integrated into this factor. 
CF12: Visible results of Using Covering, Seedling Number, and Drainage

CF12 explained 3.213 percent of the variance and observability of three component technologies occurred in this factor. These were observability of covering (0.833), observability of seedlings per hill (0.813), and observability of drainage (0.791).

CF13: Advantages of Harvester and Benefit of Population

In CF13, two variables-the relative advantage of the combined harvester and benefit of the population-were reduced to a common factor, which explained 1.95 percent of the variance.

CF14: Visible results of Using Planting Depth

The result showed that one variable — planting depth (0.725)—occurred in this common factor, which explained 1.748 percent of the variance.

\section{CF15: Advantages of Submerging}

The result showed 1.719 percent of the variance and one variable—submerging (0.609)—was observed in this common factor.

\section{CF16: Compatible with Nursery}

The common factor CF16 explained 1.624 percent of the variance and contained only one variable: compatibility of systematic care of nursery (0.702).

Table 7. Rotated factor matrix of farmers' perception.

\begin{tabular}{|c|c|c|c|}
\hline \multirow[b]{2}{*}{ Farmers' Perception } & \multicolumn{3}{|c|}{ Factors } \\
\hline & $\begin{array}{c}\text { Factor } \\
\text { Loading }\end{array}$ & $\begin{array}{c}\text { Variance } \\
\text { Explained (\%) }\end{array}$ & Eigenvalues \\
\hline Trialability of GAPs (CF1) & & 14.879 & 10.415 \\
\hline Trialability of quality seeds & 0.915 & & \\
\hline Trialability of sparse sowing & 0.933 & & \\
\hline Trialability of covering & 0.883 & & \\
\hline Trialability of systematic care of nursery & 0.542 & & \\
\hline Trialability of uprooting \& transplanting & 0.641 & & \\
\hline Trialability of planting depth & 0.762 & & \\
\hline Trialability of seedlings per hill & 0.83 & & \\
\hline Trialability of plant population & 0.836 & & \\
\hline Trialability of alternate wetting \& drying (AWD) & 0.853 & & \\
\hline Trialability of pest \& disease management & 0.837 & & \\
\hline Trialability of balanced inputs & 0.826 & & \\
\hline Trialability of submerging & 0.853 & & \\
\hline Trialability of drainage & 0.896 & & \\
\hline Trialability of combine harvester & 0.893 & & \\
\hline $\begin{array}{c}\text { Advantages of GAPs in rice production (except Submerging \& } \\
\text { harvester) (CF2) }\end{array}$ & & 6.5 & 4.55 \\
\hline Relative advantages of quality seeds & 0.64 & & \\
\hline Relative advantages of sparse sowing & 0.577 & & \\
\hline Relative advantages of covering & 0.706 & & \\
\hline Relative advantages of systematic care of nursery & 0.668 & & \\
\hline Relative advantages of uprooting \& transplanting & 0.631 & & \\
\hline Relative advantages of planting depth & 0.683 & & \\
\hline Relative advantages of seedlings per hill & 0.445 & & \\
\hline Relative advantages of plant population & 0.637 & & \\
\hline Relative advantages of alternate wetting \& drying & 0.531 & & \\
\hline Relative advantages of pest \& disease management & 0.357 & & \\
\hline Relative advantages of balanced inputs & 0.507 & & \\
\hline Relative advantages of drainage & 0.55 & & \\
\hline
\end{tabular}


Table 7. Cont.

\begin{tabular}{|c|c|c|c|}
\hline \multirow[b]{2}{*}{ Farmers' Perception } & \multicolumn{3}{|c|}{ Factors } \\
\hline & $\begin{array}{c}\text { Factor } \\
\text { Loading }\end{array}$ & $\begin{array}{c}\text { Variance } \\
\text { Explained (\%) }\end{array}$ & Eigenvalues \\
\hline $\begin{array}{c}\text { Visible results of using nursery, pest \& water management \& } \\
\text { harvester (CF3) }\end{array}$ & & 5.408 & 3.786 \\
\hline Observability of sparse sowing & 0.864 & & \\
\hline Observability of systematic care of nursery & 0.822 & & \\
\hline Observability of pest \& disease management & 0.808 & & \\
\hline Observability of submerging & 0.783 & & \\
\hline Observability of combine harvester & 0.774 & & \\
\hline Compatible with sowing, transplanting, inputs \& drainage (CF4) & & 5.125 & 3.587 \\
\hline Compatibility of sparse sowing & 0.895 & & \\
\hline Compatibility of uprooting \& transplanting & 0.61 & & \\
\hline Compatibility of plant population & 0.832 & & \\
\hline Compatibility of balanced inputs & 0.837 & & \\
\hline Compatibility of drainage & 0.887 & & \\
\hline $\begin{array}{l}\text { Visible results of using quality seeds, transplanting, AWD \& inputs } \\
\text { (CF5) }\end{array}$ & & 4.552 & 3.186 \\
\hline Observability of quality seeds & 0.857 & & \\
\hline Observability of uprooting \& transplanting & 0.838 & & \\
\hline Observability of alternate wetting \& drying & 0.829 & & \\
\hline Observability of balanced inputs & 0.811 & & \\
\hline Complexity of nursery, population \& harvester (CF6) & & 4.543 & 3.18 \\
\hline Complexity of systematic care of nursery & 0.906 & & \\
\hline Complexity of plant population & 0.901 & & \\
\hline Complexity of combine harvester & 0.905 & & \\
\hline $\begin{array}{c}\text { Complexity of sowing, planning depth, pest management \& } \\
\text { submerging (CF7) }\end{array}$ & & 4.405 & 3.084 \\
\hline Complexity of sparse sowing & 0.826 & & \\
\hline Complexity of planting depth & 0.841 & & \\
\hline Complexity of pest \& disease management & 0.711 & & \\
\hline Complexity of submerging & 0.783 & & \\
\hline Complexity of quality seeds, transplanting, AWD \& inputs (CF8) & & 4.151 & 2.905 \\
\hline Complexity of quality seeds & 0.918 & & \\
\hline Complexity of uprooting \& transplanting & 0.903 & & \\
\hline Complexity of alternate wetting \& drying & 0.584 & & \\
\hline Complexity of balanced inputs & 0.827 & & \\
\hline $\begin{array}{c}\text { Compatible with seeds, seedling number, pest management \& } \\
\text { submerging (CF9) }\end{array}$ & & 4.056 & 2.839 \\
\hline Compatibility of quality seeds & 0.818 & & \\
\hline Compatibility of seedlings per hill & 0.787 & & \\
\hline Compatibility of pest \& disease management & 0.787 & & \\
\hline Compatibility of submerging & 0.791 & & \\
\hline Compatible with covering, depth, AWD \& harvester (CF10) & & 3.944 & 2.761 \\
\hline Compatibility of covering & 0.832 & & \\
\hline Compatibility of planting depth & 0.738 & & \\
\hline Compatibility of alternate wetting \& drying & 0.728 & & \\
\hline Compatibility of combine harvester & 0.867 & & \\
\hline Complexity of covering, seedling number \& drainage (CF11) & & 3.670 & 2.569 \\
\hline Complexity of covering & 0.801 & & \\
\hline Complexity of seedlings per hill & 0.783 & & \\
\hline Complexity of drainage & 0.798 & & \\
\hline Visible results of using covering, seedling number \& drainage (CF12) & & 3.213 & 2.249 \\
\hline Observability of covering & 0.833 & & \\
\hline Observability of seedlings per hill & 0.813 & & \\
\hline Observability of drainage & 0.791 & & \\
\hline Advantage of harvester \& benefit of population (CF13) & & 1.95 & 1.365 \\
\hline Relative advantages of combine harvester & 0.602 & & \\
\hline Observability of plant population & 0.335 & & \\
\hline Visible results of using planting depth (CF14) & & 1.748 & 1.223 \\
\hline Observability of planting depth & 0.725 & & \\
\hline
\end{tabular}


Table 7. Cont.

\begin{tabular}{cccc}
\hline Farmers' Perception & \multicolumn{2}{c}{ Factors } \\
\cline { 2 - 4 } & $\begin{array}{c}\text { Factor } \\
\text { Loading }\end{array}$ & $\begin{array}{c}\text { Variance } \\
\text { Explained (\%) }\end{array}$ & Eigenvalues \\
\hline $\begin{array}{c}\text { Advantage of submerging (CF15) } \\
\text { Relative advantages of submerging }\end{array}$ & 0.609 & 1.719 & 1.204 \\
\hline $\begin{array}{c}\text { Compatibility of nursery (CF16) } \\
\text { Compatibility of systematic care of nursery }\end{array}$ & 0.702 & 1.624 & 1.137 \\
\hline Total variance explained & \multicolumn{2}{c}{71.487} \\
\hline
\end{tabular}

Note: (1) Factor loading taken is over 0.3, and eigenvalues is over 1. (2) Kaiser-Meyer-Olkin of sampling adequacy

$(\mathrm{KMO})=0.828,(3) \mathrm{CF}=$ common factor, and $(4) \mathrm{AWD}=$ alternate wetting and drying.

\subsubsection{Results of Cluster Analysis}

Based on 16 common factors of farmers' perception of GAPs in rice production, farmers were categorized into groups by cluster analysis. According to the dendrogram (Figure 4) of cluster analysis by the hierarchical clustering method, farmers could be classified into three groups. This implies that Cluster 3 is different from Clusters 1 and 2, while Cluster 1 and Cluster 2 are similar. The mean value was assumed to be above 0.000 "high perception" because most of the mean values were less than 1 . The accurate perception of GAPs in rice production for each cluster is summarized in Table 8.

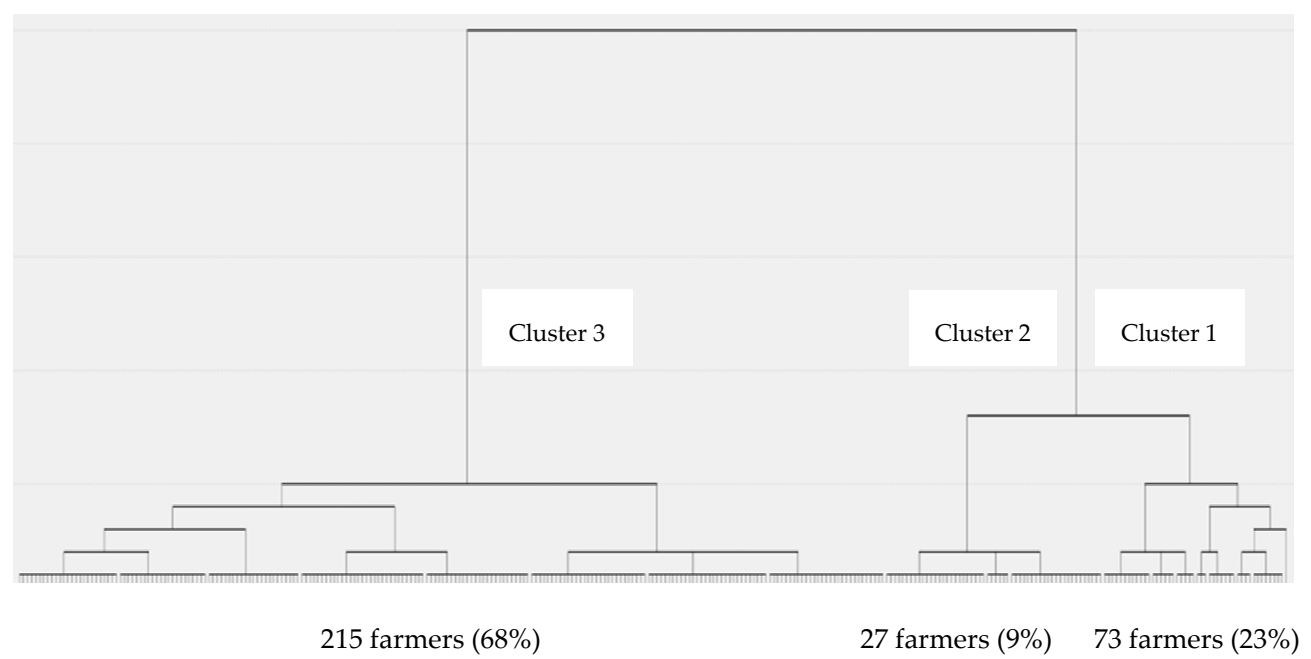

Figure 4. Dendrogram of farmers' perception by cluster analysis.

Cluster 1 (73 farmers: 23\%)

Compared with Cluster 2, a remarkable difference is found in CF2 (relative advantage), CF4 (compatibility), CF1 (trialability), and CF3 and CF5 (observability). "The lowest perception of CF1 but the highest perception of CF3" is featured.

\section{Cluster 2 (27 farmers: 9\%)}

Similarly, compared with Cluster 1, a remarkable difference is found in CF2 (relative advantage), CF4 and CF9 (compatibility), CF7 (complexity), CF1 (trialability), and CF3 and CF5 (observability). "The lowest perception of CF3 and CF5 and the lower perception of CF1" is featured. In addition, the other $\mathrm{CFs}$ show a contrast when the mean is positive and negative.

Cluster 3 (215 farmers: 68\%)

The perception, on the whole, was neither high nor low, but in Cluster 1 and Cluster 2, it is a feature that only CF1 (trialability) was highly perceived. 
Table 8. Farmers' perception of GAPs in rice production by group (based on cluster analysis).

\begin{tabular}{|c|c|c|c|c|c|c|c|c|c|c|c|c|c|c|c|c|c|}
\hline \multirow{3}{*}{ * Cluster } & \multirow{3}{*}{$\begin{array}{c}\text { No. } \\
\text { of Farmers } \\
(\%)\end{array}$} & \multicolumn{16}{|c|}{ Mean Values (Standard Deviation) } \\
\hline & & \multicolumn{3}{|c|}{$\begin{array}{l}\text { Relative Advantages } \\
\text { (3 CFs) }\end{array}$} & \multicolumn{4}{|c|}{ Compatibility (4 CFs) } & \multicolumn{4}{|c|}{ Complexity (4 CFs) } & \multicolumn{2}{|c|}{$\begin{array}{l}\text { Trialability } \\
(1 \mathrm{CF})\end{array}$} & \multicolumn{3}{|c|}{ Observability (4 CFs) } \\
\hline & & CF2 & CF13 & CF15 & CF4 & CF9 & CF10 & CF16 & CF6 & CF7 & CF8 & CF11 & CF1 & CF3 & CF5 & CF12 & CF14 \\
\hline 1 & $\begin{array}{c}73 \\
(23 \%)\end{array}$ & $\begin{array}{c}0.471 \\
(2.749)\end{array}$ & $\begin{array}{l}-0.011 \\
(1.273)\end{array}$ & $\begin{array}{l}-0.011 \\
(0.963)\end{array}$ & $\begin{array}{c}0.435 \\
(2.315)\end{array}$ & $\begin{array}{c}0.11 \\
(1.718)\end{array}$ & $\begin{array}{l}0.148 \\
(1.51)\end{array}$ & $\begin{array}{l}-0.01 \\
(0.957)\end{array}$ & $\begin{array}{l}-0.002 \\
(2.045)\end{array}$ & $\begin{array}{c}0.135 \\
(1.995)\end{array}$ & $\begin{array}{c}-0.084 \\
(1.8)\end{array}$ & $\begin{array}{c}0.014 \\
(1.405)\end{array}$ & $\begin{array}{l}-5.096 \\
(1.773)\end{array}$ & $\begin{array}{c}1.348 \\
(2.092)\end{array}$ & $\begin{array}{c}0.327 \\
(2.166)\end{array}$ & $\begin{array}{c}0.046 \\
(1.139)\end{array}$ & $\begin{array}{l}-0.036 \\
(0.932)\end{array}$ \\
\hline 2 & $\begin{array}{c}27 \\
(9 \%) \\
\end{array}$ & $\begin{array}{l}-0.574 \\
(1.649) \\
\end{array}$ & $\begin{array}{c}0.237 \\
(1.164) \\
\end{array}$ & $\begin{array}{l}-0.055 \\
(1.673) \\
\end{array}$ & $\begin{array}{l}-0.355 \\
(2.073) \\
\end{array}$ & $\begin{array}{c}-0.419 \\
(1.4) \\
\end{array}$ & $\begin{array}{c}0.677 \\
(1.375) \\
\end{array}$ & $\begin{array}{c}0.123 \\
(1.084) \\
\end{array}$ & $\begin{array}{l}-0.119 \\
(1.757) \\
\end{array}$ & $\begin{array}{c}0.51 \\
(1.698) \\
\end{array}$ & $\begin{array}{c}0.000 \\
(1.657)\end{array}$ & $\begin{array}{c}0.219 \\
(1.724) \\
\end{array}$ & $\begin{array}{l}-1.985 \\
(2.737) \\
\end{array}$ & $\begin{array}{l}-5.192 \\
(1.918) \\
\end{array}$ & $\begin{array}{l}-1.495 \\
(2.396) \\
\end{array}$ & $\begin{array}{l}-0.039 \\
(1.651) \\
\end{array}$ & $\begin{array}{l}-0.12 \\
(1.381) \\
\end{array}$ \\
\hline 3 & $\begin{array}{c}215 \\
(68 \%)\end{array}$ & $\begin{array}{l}-0.088 \\
(2.363)\end{array}$ & $\begin{array}{c}-0.026 \\
(1.03)\end{array}$ & $\begin{array}{l}0.011 \\
(0.95)\end{array}$ & $\begin{array}{l}-0.103 \\
(1.818)\end{array}$ & $\begin{array}{l}0.015 \\
(1.394)\end{array}$ & $\begin{array}{l}-0.135 \\
(1.256)\end{array}$ & $\begin{array}{l}-0.012 \\
(1.035)\end{array}$ & $\begin{array}{l}0.016 \\
(1.597)\end{array}$ & $\begin{array}{c}-0.11 \\
(1.467)\end{array}$ & $\begin{array}{l}0.029 \\
(1.39)\end{array}$ & $\begin{array}{c}-0.032 \\
(1.24)\end{array}$ & $\begin{array}{c}1.98 \\
(1.526)\end{array}$ & $\begin{array}{c}0.194 \\
(1.467)\end{array}$ & $\begin{array}{c}0.077 \\
(1.502)\end{array}$ & $\begin{array}{l}-0.011 \\
(1.127)\end{array}$ & $\begin{array}{c}0.027 \\
(1.051)\end{array}$ \\
\hline
\end{tabular}

Note: $(1)^{*}=$ Cluster analysis by hierarchical clustering method, and CF = common factor. (2) CF1 = Trialability of GAPs, CF2 = Advantages of GAPs (except submerging \& harvester), CF3 $=$ Benefit of nursery, pests management, submerging and harvester, CF4 = Compatible with sowing, transplanting, inputs and drainage, CF5 = Benefit of quality seeds, nursery, AWD and inputs, CF6 = Difficulties in nursery, population and harvester, CF7 = Difficulties in sowing, depth, pest management \& submerging, CF8 = Difficulties in quality seeds, transplanting, AWD and inputs, $\mathrm{CF} 9=$ Compatible with quality seeds, seedling number, pests management, $\mathrm{CF} 10=$ Compatible with covering, depth, $\mathrm{AWD}$ and harvester, $\mathrm{CF} 11=\mathrm{Difficulties}$ in covering, seedling number \& drainage, CF12 = Benefit of covering, seedling number and drainage, CF13 = Advantage of harvester \& Benefit of population, CF14 = Benefit of planting depth, CF15 = Advantage of submerging, and CF16 = Compatible with nursery. 


\subsection{Determinants of Farmers' Perception of GAPs in Rice Production}

As shown in Table 5, relating to five characteristics of GAPs in rice production, measuring significant variance in terms of the percentage of farmers (less than $60 \%$ ) by Likert scale was limited to the compatibility of nine component technologies of GAPs in rice production: GAP2 (Sparse sowing), GAP3 (Covering), GAP5 (Uprooting and transplanting), GAP6 (Planting depth), GAP8 (Plant population), GAP9 (Alternate wetting and drying), and GAP11 (Balance inputs), GAP13 (Drainage), and GAP14 (Combine harvester). Therefore, the compatibility of nine component technologies of GAPs in rice production was selected as the dependent variable of the binary logit model. Since the values of variance inflation factors (VIFs) for independent variables were less than 5 (maximum value $=2.70)$, there was no multicollinearity among the independent variables.

Table 9 indicates that only eight independent variables were found to have a significant association with farmers' perception of the compatibility of GAPs in rice production, while there was no influencing factor on farmers' perception of the compatibility of GAP2 (Sparse sowing), GAP5 (Uprooting and Transplanting), and GAP9 (Alternate wetting and drying). These variables were gender and education of household head, farmland size, access to credit, income from crop production, contact with extension workers, receiving agricultural information from the Department of Agriculture (DOA), and receiving GAPs in rice production training. Among these, contact with extension agents and receiving agricultural information from DOA were positively associated with farmers' perception of the compatibility of GAPs in rice production.

As to personal characteristics, gender and education were determinants of farmers' perception of the compatibility of GAP8 (Plant population). Gender showed a negative correlation with farmers' perception on the compatibility of GAP8. This contradicts the finding of [20]. Male farmers show a negative association with their perception of the compatibility of GAP8 (Plant population). This is likely because male farmers perceived that the recommended plant population is inconsistent at transplanting time. Education negatively predicted farmers' perception of the compatibility of GAP8 (Plant population) and GAP11 (Balanced inputs). The result implies that the probability of farmers' perception of the compatibility of GAP8 (Plant population) and GAP11 (Balanced inputs) is lower for more highly educated farmers compared to less educated farmers.

In farming characteristics, farmland size showed a negative correlation with only farmers' perception of the compatibility of GAP3 (Covering). This coincides with previous findings [21,57], and is likely because larger farms require more time, experience, and management capacity to apply farmyard manure on the seedbed.

Regarding economic characteristics, access to credit was a determinant of only farmers' perception of the compatibility of GAP3 (Covering), which shows a negative relationship and in is line with the finding of [42]. The result reveals that farmers with access to credit were less likely to perceive the compatibility of GAP3 (Covering). Similarly, income from crop production was negatively correlated with only farmers' perception of the compatibility of GAP13 (Drainage). This contradicted the finding of [57]. The result implies that farmers who had higher income from crop production did not perceive the compatibility of timely drainage before two weeks of harvesting.

Among institutional characteristics, determinants of farmers' perception of the compatibility of GAPs in rice production were found for GAP3 (Covering), GAP6 (Planting depth), GAP8 (Plant population), and GAP14 (Combine harvester). Contact with extension agents was positively correlated with farmers' perception of the compatibility of GAP3 (Covering) and GAP14 (Combine harvester), which is in line with some other findings [27,58]. This implies that the improvement of their agricultural knowledge gained through such contact increases the probability of farmers' perceiving the compatibility of GAP3 and GAP14. 
Table 9. The estimated coefficients of the binary logit model for the compatibility of GAPs in rice production.

\begin{tabular}{|c|c|c|c|c|c|c|c|c|c|c|c|c|c|c|c|c|c|c|c|}
\hline \multirow{2}{*}{$\begin{array}{l}\text { Independent } \\
\text { Variables }\end{array}$} & \multicolumn{2}{|c|}{ GAP2 } & \multicolumn{2}{|c|}{ GAP3 } & \multicolumn{2}{|c|}{ GAP5 } & \multicolumn{2}{|c|}{ GAP6 } & \multicolumn{2}{|c|}{ GAP8 } & \multicolumn{2}{|c|}{ GAP9 } & \multicolumn{2}{|c|}{ GAP11 } & \multicolumn{2}{|c|}{ GAP13 } & \multicolumn{2}{|c|}{ GAP14 } & \multirow{2}{*}{ VIF } \\
\hline & Coef. & SE & Coef. & SE & Coef. & SE & Coef. & SE & Coef. & SE & Coef. & SE & Coef. & SE & Coef. & SE & Coef. & SE & \\
\hline Constant & 1.15 & 1.374 & 0.109 & 1.155 & 0.226 & 1.109 & -2.131 & 1.157 & 2.111 & 1.414 & -1.739 & 1.227 & 1.208 & 1.143 & 0.266 & 0.979 & 0.682 & 1.175 & - \\
\hline Age & 0.015 & 0.016 & 0.007 & 0.015 & 0.01 & 0.015 & 0.023 & 0.016 & 0.005 & 0.015 & 0.006 & 0.015 & -0.002 & 0.015 & 0.009 & 0.015 & 0.009 & 0.015 & 2.7 \\
\hline Gender & -1.682 & 1.12 & -0.552 & 0.823 & -0.663 & 0.794 & 0.027 & 0.795 & $-2.416 * *$ & 1.196 & 0.564 & 0.88 & -0.408 & 0.814 & -0.451 & 0.209 & -1.034 & 0.881 & 1.12 \\
\hline Marital Status & 0.002 & 0.623 & 0.142 & 0.604 & -0.16 & 0.585 & -0.124 & 0.614 & 0.897 & 0.641 & 0.581 & 0.699 & -0.159 & 0.606 & 0.145 & 0.643 & -0.05 & 0.598 & 1.17 \\
\hline Education & -0.01 & 0.039 & 0.048 & 0.039 & -0.007 & 0.038 & 0.021 & 0.04 & $-0.078 *$ & 0.04 & -0.01 & 0.04 & -0.071 * & 0.039 & -0.045 & 0.04 & -0.009 & 0.038 & 1.21 \\
\hline Farming experience & -0.013 & 0.014 & 0.006 & 0.013 & -0.019 & 0.013 & -0.008 & 0.013 & -0.012 & 0.013 & 0.007 & 0.013 & -0.005 & 0.013 & -0.014 & 0.014 & 0.004 & 0.013 & 2.4 \\
\hline Household size & -0.12 & 0.111 & -0.078 & 0.111 & -0.06 & 0.109 & 0.046 & 0.114 & -0.135 & 0.112 & 0.789 & 0.112 & -0.087 & 0.11 & -0.103 & 0.112 & 0.034 & 0.109 & 2.32 \\
\hline Farmland size & -0.005 & 0.011 & $-0.025 * *$ & 0.013 & -0.003 & 0.011 & -0.001 & 0.012 & -0.008 & 0.012 & -0.017 & 0.014 & -0.004 & 0.012 & 0.001 & 0.012 & -0.014 & 0.012 & 1.73 \\
\hline Active labor force & 0.147 & 0.147 & 0.113 & 0.132 & 0.064 & 0.13 & 0.056 & 0.136 & 0.065 & 0.135 & 0.001 & 0.134 & 0.005 & 0.132 & 0.176 & 0.137 & 0.05 & 0.131 & 2.61 \\
\hline Access to credit & -0.029 & 0.443 & $-0.901 *$ & 0.472 & 0.555 & 0.442 & -0.023 & 0.473 & -0.669 & 0.461 & -0.389 & 0.45 & 0.179 & 0.441 & -0.275 & 0.452 & -0.648 & 0.446 & 1.09 \\
\hline $\begin{array}{c}\text { Income from crop } \\
\text { production }\end{array}$ & -0.036 & 0.174 & 0.004 & 0.174 & 0.112 & 0.17 & 0.026 & 0.178 & 0.14 & 0.175 & 0.004 & 0.179 & -1.18 & 0.172 & $-0.303 *$ & 0.175 & 0.084 & 0.171 & 1.53 \\
\hline $\begin{array}{l}\text { Contact with } \\
\text { extension workers }\end{array}$ & 0.03 & 0.039 & $0.133^{* *}$ & 0.054 & 0.04 & 0.038 & 0.05 & 0.037 & 0.019 & 0.037 & 0.01 & 0.039 & 0.04 & 0.038 & 0.04 & 0.041 & $0.081 *$ & 0.045 & 1.28 \\
\hline $\begin{array}{l}\text { Receiving } \\
\text { agricultural } \\
\text { information }\end{array}$ & 0.602 & 0.376 & 0.371 & 0.381 & 0.056 & 0.369 & 0.127 & 0.389 & $0.791 * *$ & 0.395 & -0.14 & 0.379 & 0.602 & 0.378 & 0.365 & 0.383 & 0.127 & 0.373 & 1.1 \\
\hline $\begin{array}{l}\text { Receiving GAP } \\
\text { training }\end{array}$ & -0.24 & 0.289 & 0.031 & 0.291 & -0.001 & 0.284 & -0.88 & 0.322 & -0.275 & 0.9 & -0.163 & 0.298 & -0.424 & 0.288 & 0.019 & 0.289 & -0.17 & 0.284 & 1.21 \\
\hline $\begin{array}{l}\text { Membership of local } \\
\text { farmers' association }\end{array}$ & 0.204 & 0.253 & 0.027 & 0.252 & -0.048 & 0.248 & 0.231 & 0.259 & 0.288 & 0.254 & -0.14 & 0.257 & 0.222 & 0.252 & 0.193 & 0.254 & -0.131 & 0.248 & 1.17 \\
\hline $\begin{array}{l}\text { Membership of seed } \\
\text { growers' association }\end{array}$ & 0.735 & 0.532 & 0.271 & 0.496 & 0.483 & 0.483 & -0.093 & 0.512 & 0.788 & 0.517 & 0.116 & 0.504 & 0.632 & 0.501 & 0.88 & 0.539 & 0.16 & 0.48 & 1.24 \\
\hline Pseudo $R^{2}$ & \multicolumn{2}{|c|}{0.214} & \multicolumn{2}{|c|}{0.475} & \multicolumn{2}{|c|}{0.220} & \multicolumn{2}{|c|}{0.377} & \multicolumn{2}{|c|}{0.785} & \multicolumn{2}{|c|}{0.221} & \multicolumn{2}{|c|}{0.412} & \multicolumn{2}{|c|}{0.635} & \multicolumn{2}{|c|}{0.271} & $\begin{array}{lll}- & -\end{array}$ \\
\hline
\end{tabular}

Note:(1) Coef. = coefficient, SE = standard error, VIF = variance inflation factor, ${ }^{* * *}=$ significant at $1 \%$ level, ${ }^{* *}=$ significant at $5 \%$ level, and $*=$ significant at $10 \%$ level. $(2)$ GAP2 $=$ Sparse sowing, GAP3 = Covering, GAP5 = Uprooting \& transplanting, GAP6 = Planting depth, GAP8 = Plant population, GAP9 = Alternate wetting \& drying, GAP11 = Balanced inputs, GAP13

$=$ Drainage, and GAP14 = Combine harvester, and (3) Pseudo $\mathrm{R}^{2}$ shows the fitness of model (higher is better for a given estimator). 
Additionally, receiving agricultural information was positively associated with farmers' perception of the compatibility of GAP8 (Plant population), which is in line with the finding of [47]. It is likely that agricultural information helps farmers to understand the compatibility of GAP8. Meanwhile, there was a negative and significant (at the $1 \%$ level) relationship between receiving GAPs in rice production training and farmers' perception of the compatibility of GAP6 (Planting depth), though this contradicts the finding of [55]. The result is likely because farmers are afraid that control of planting depth at transplanting time depends on the skillfulness of transplanting laborer.

\section{Conclusions}

The present study revealed that almost all farmers perceived that all components of GAPs in rice production have three characteristics, namely, relative advantage, complexity, and observability. In perception of compatibility, among 14 component technologies of GAPs in rice production, farmers perceived that GAP1 (Quality seed), GAP4 (Systematic care of nursery), GAP7 (Seedlings per hill), GAP10 (Pest and disease management), and GAP12 (Submerging) were compatible with their farming practices. Farmers perceived that all component technologies of GAPs in rice production, with the exception of GAP13 (Drainage), could be easily tried on their farms. Based on the structure of farmers' perception of GAPs in rice production, farmers were classified into three groups. The differences (meaningful variance) in perception among farmers were identified in "trialability" (CF1) and part of "observability", that is, CF3 and CF5.

According to the result of the binary logit model, farmers' perception was significantly influenced by eight variables: gender, education, farmland size, access to credit, income from crop production, contact with extension agents, receiving agricultural information from the Department of Agriculture (DOA), and receiving GAPs in rice production training. Some agricultural policies and extension activities are needed to enhance farmers' perception of the compatibility of six components, namely, GAP3 (Covering), GAP6 (Planting depth), GAP8 (Plant population), GAP11 (Balanced inputs), GAP13 (Drainage), and GAP14 (Combine harvester). First, the implementation of GAPs in rice production should focus mainly on low-income farmers who own small amounts of farmland. Second, MOAI should reform the credit plan for farmers who wish to accept GAPs in rice production by, for example, increasing the amount of credit for rice production with a low interest rate. Third, extension workers should have regular contact with farmers to enhance farmers' perception of the compatibility of GAPs in rice production. Finally, more agricultural information should be provided, especially for farmers who have larger farms and higher incomes, concerning the advantages of using GAPs in rice production.

Author Contributions: Conceptualization, S.P.O. and K.U.; Data curation, S.P.O.; Formal analysis, S.P.O.; Methodology, S.P.O. and K.U.; Supervision, K.U.; Writing—original draft, S.P.O.; Writing一review \& editing, K.U. All authors have read and agreed to the published version of the manuscript.

Funding: This research was financially supported by YAU-JICA (Yezin Agricultural University and Japan International Cooperation Agency) Technical Cooperation Project, Myanmar.

Acknowledgments: We would like to give the deepest gratitude to YAU-JICA Technical Cooperation Project for providing all expenditures of this research. The first author is very grateful to the Japan International Cooperation Agency (JICA) for offering the scholarship for doctoral study at the Graduate School of International Development (GSID), Nagoya University, Japan. The enumerators are highly acknowledged for their participation in data collection. We wish to express our gratitude to the farmers from the study area for their contributions, Director, Deputy Directors of Ayeyarwady Region, and all officers from Myaungmya District, DOA, MOALI, Myanmar, for their kind cooperation about data collection of this study.

Conflicts of Interest: We declare that there is no conflict of interest.

\section{References}

1. Raitzer, D.A.; Wong, L.C.Y.; Samson, J.N.G. Myanmar's Agriculture Sector: Unlocking The Potential for Inclusive Growth; Asia Development Bank: Mandaluyong, Philippines, 2015; Volume 470. 
2. Haefele, S.M.; Johnson, D.E.; Diallo, S.; Wopereis, M.C. Improved Soil Fertility and Weed Management Is Profitable for Irrigated Rice Farmers in Sahelian West Africa. Field Crop. Res. 2000, 66, 101-113. [CrossRef]

3. Becker, M.; Johnson, D.E. Improved Water Control and Crop Management Effects on Lowland Rice Productivity in West Africa. Nutr. Cycl. Agroecosystems 2001, 59, 119-127. [CrossRef]

4. Poussin, J.C.; Diallo, Y.; Legoupil, J.C. Improved Collective Decision Making in Action for Irrigated Rice Farmers in the Senegal River Valley. J. Agric. Syst. 2006, 89, 299-323. [CrossRef]

5. Krupnik, T.J.; Shennan, C.; Settle, W.H.; Demont, M.; Ndiaye, A.B.; Rodenburg, J. Improving Irrigated Rice Production in the Senegal River Valley Through Experiential Learning and Innovation. J. Agric. Syst. 2012, 109, 101-112. [CrossRef]

6. Tanaka, A.; Saito, K.; Azoma, K.; Kobayashi, K. Factors Affecting Variation in Farm Yields of Irrigated Lowland rice in southern central Benin. Eur. J. Agron. 2013, 44, 46-53. [CrossRef]

7. Senthilkumar, K.; Bindraban, P.S.; Thiyagarajan, T.M.; Ridder, N. Modified rice cultivation in Tamil Nadu, India: Yield Gains and Farmers' (Lack of) Acceptance. J. Agric. Syst. 2008, 98, 82-94. [CrossRef]

8. DOA (Department of Agriculture). Annual Report of Rice Division; Department of Agriculture, Ministry of Agriculture and Irrigation: Nay Pyi Taw, Myanmar, 2016.

9. MOAI (Ministry of Agriculture, Livestock, and Irrigation). Myanmar Agriculture in Brief; Ministry of Agriculture, Livestock, and Irrigation: Nay Pyi Taw, Myanmar, 2013.

10. IRRI (International Rice Research Institute). Bridging the "GAP" Makes Farmers Wealthier. Available online: http://books.irri.org/AR2010_content.pdf (accessed on 3 February 2012).

11. Mausch, K.; Milthofer, D.; Asfaw, S.; Waibel, H. Impact of EurepGAP Standard in Kenya: Comparing Smallholders to Large-scale Vegetable Producers. In Proceedings of the Conference on International Agricultural Research for Development, Bonn, Germany, 11-13 October 2006.

12. Ministry of Agriculture and Cooperatives. Coffee Strategy 2009-2013 (in Thai); Ministry of Agriculture and Cooperatives: Bangkok, Thailand, 2009.

13. Ryan, R.L.; Erickson, D.L.; Young, R.D. Farmers' Motivations for Adopting Conservation Practices Along Riparian Zones in a mid-Western Agricultural Watershed. J. Environ. Plan. Manag. 2003, 46, 19-37. [CrossRef]

14. Salakpetch, S. Quality Management System: Good Agricultural Practices (GAP) for On-farm Production in Thailand. In Good Agricultural Practice (GAP) in Asia and Oceania. Proceedings international seminar on Technology Development for Good Agricultural Practice in Asia and Oceania, Tsukuba, Japan, 24-28 October 2005; Hu, S., Bejosano-Gloria, G., Eds.; Food and Fertilizer Technology Center: Taipei, Taiwan, 2007.

15. Van, D.M. Exclusion of Small-scale Farmers From Coordinated Supply Chain: Market Failure, policy failure, or just economies of scale? In Agro-Food Chains and Networks for Development; Ruben, R., Slingerland, M., Nijhoff, H., Eds.; Springer Netherlands: Heidelberg, Germany, 2006; pp. 209-217.

16. DOA (Department of Agriculture). Phamplet for Good Agricultural Practices in Rice Production; Department of Agriculture, Ministry of Agriculture and Irrigation: Nay Pyi Taw, Myanmar, 2011.

17. Banzon, A.T.; Mojica, L.E.; Angela, A.; Cielo, A.A. Adoption of Good Agricultural Practices (GAP) in the Philippines: Challenges, Issues, and Policy Imperatives. Policy Brief Ser. 2013, 2013, 1-2.

18. Hobbs, J.E. Incentives for the Adoption of Good Agricultural Practices. In Background Paper for the FAO Expert Consultation on a Good Agricultural Practice Approach, Rome, Italy, 10-12 November 2003; Food and Agriculture Organization of the United Nations: Rome, Italy, 2003.

19. DOA (Department of Agriculture). Annual Report of Rice Division; Department of Agriculture, Ministry of Agriculture and Irrigation: Nay Pyi Taw, Myanmar, 2017.

20. Negatu, W.; Parikh, A. The Impact of Perception and Other Factors on the Adoption of Agricultural Technology in the Moret and JiruWoreda of Ethiopia. J. Agric. Econ. 1999, 21, 205-216. [CrossRef]

21. Bagheri, A.; Fami, H.S.; Rezvanfar, A.; Asadi, A.; Yazdani, S. Perceptions of Paddy Farmers towards Sustainable Agricultural Technologies: Case of Haraz Catchments Area in Mazandaran Province of Iran. Am. J. Appl. Sci. 2008, 5, 1384-1391. [CrossRef]

22. Emmanuel, A.-D. Farmers' Perception of Agricultural Technologies a Case of Some Improved Crop Varieties in Ghana. Agric. For. Fish. 2014, 3, 13-16.

23. Agahi, H.; Ghambarali, R.; Afsharzade, N. Wheat Farmers' Perceptions of Sustainable Agriculture: The Case of Kermanshah Province of Iran. Eup. J. Agric. Sci. 2011, 3, 74-80. 
24. Smathers, W.M., Jr. Farmers' Attitudes: Omitted Factors in Nonpoint Pollution Policy. In Perceptions, Attitudes, and Risk: Overlooked Variables in Formulating Public Policy on Soil and Water Conservation and Water Quality-An Organized Symposiym; US Department of Agriculture: Washington, DC, USA, 1982; pp. 38-49.

25. Byerlee, D.; Hesse de Polanco, E. Farmers' Stepwise Adoption of Technological Packages: Evidence from the Mexican Altiplano. Am. J. Agric. Econ. 1986, 68, 519-527. [CrossRef]

26. Leathers, H.D.; Smale, M. Bayesian Approach to Explaining Sequential Adoption of Components of a Technical Package. Am. J. Agric. Econ. 1991, 73, 734-742. [CrossRef]

27. Moges, D.M.; Taye, A.A. Determinants of Farmers' Perception to Invest in Soil and Water Conservation Technologies in the North-Western Highlands of Ethiopia. Int. Soil Water Conserv. Res. 2017, 5, 56-61. [CrossRef]

28. Jamal, K.; Kamarulzaman, N.H.; Abdullah, A.R.; Ismail, M.M. Adoption of Fragrant Rice Farming: The Case of Paddy Farmers in the East Coast Malaysia. UMK Procedia 2014, 1, 8-17. [CrossRef]

29. Tatlidil, F.F.; Boz, I.; Tatlidil, H. Farmers' Perception of Sustainable Agriculture and Its Determinants: A Case Study in Kahramanmaras Province of Turkey. Environ. Dev. Sustain. 2009, 11, 1091-1106. [CrossRef]

30. Thompson, N.M.; Bir, C.; Widmar, D.A.; Mintert, J.R. Farmer Perceptions of Precision Agriculture Technology Benefits. J. Agric. Appl. Econ. 2019, 51, 142-163. [CrossRef]

31. Rogers, E.M.; Shoemakers, F.F. Communication of Innovations: A Cross-Cultural Approach, 2nd ed.; The Free Press: New York, NY, USA, 1971.

32. Alonge, A.J.; Martin, R.A. Assessment of The Adoption of Sustainable Agriculture Practices: Implications for agricultural education. J. Agric. Educ. 1995, 3, 34-42. [CrossRef]

33. Rogers, E.M. Diffusion of Innovations, 5th ed.; Simon \& Schuster: New York, NY, USA, 2003.

34. Rao, S.V.N.; Rangnekar, D.V.; Dey, R.; Van Den Ban, A.W. Farmers' Perceptions of Innovation. In Handbook for Straw Feeding Systems: Principles and Applications with Emphasis on Indian Livestock Production; Singh, K., Schiele, J.B., Eds.; Wageningen University \& Research: Wageningen, The Netherlands, 1995.

35. van den Ban, A.W.; Hawkins, H.S. Agricultural Extension; Blackwell Science: Oxford, UK, 1974.

36. Maswadi, O.S.; Suharyani, A. The Effect of Farmer Characteristics on Perceptions of The Fermented Cocoa Beans Technology in Bengkayang Regency, West Kalimantan. J. Agric. Sci. Agritropica 2018, 1, 85-92. [CrossRef]

37. Winardi, J. Motivasi Dan Pemotivasian Dalam Manajemen; Raja Persada Grafindo: Jakarta, Indonesia, 2002.

38. Rogers, E.M. Diffusion of Innovations, 4th ed.; Simon \& Schuster: New York, NY, USA, 1995.

39. Banmeke, T.O.A.; Ajayi, M.T. Farmers' Perception of the Agricultural Information Resource Centre at Ago-Are, Oyo State, Nigeria. Int. J. Agric. Econ. Rural. Dev. 2008, 1, $22-29$.

40. Pongvinyoo, P.; Yamao, M.; Hosono, K. Factors Affecting the Implementation of Good Agricultural Practices (GAP) Among Coffee Farmers in Chumphon Province, Thailand. Am. J. Rural. Dev. 2014, 2, 34-39. [CrossRef]

41. Meseret, D. Determinants of Farmers' Perception of Soil and Water Conservation Practices on Cultivated Land in Ankesha District, Ethiopia. Agric. Sci. Eng. Technol. Res. 2014, 2, 1-9.

42. Ndambiri, H.K.; Ritho, C.N.; Mbogoh, S.G. An Evaluation of Farmers' Perceptions of and Adaptation to The Effect of Climate Change in Kenya. Int. J. Food Agric. Econ. 2013, 1, 75-96.

43. Sasima, F.; Suneeporn, S.; Panya, M. Farmer's Perceptions towards Economic Sustainability of Rice Farming in Peri-Urban Area, Bangkok, Thailand. Int. J. Agric. Technol. 2016, 12, 1759-1772.

44. Pinthukas, N. Farmers' Perception and Adaptation in Organic Vegetable Production for Sustainable Livelihood in Chiang Mai Province. Agric. Agric. Sci. Procedia 2015, 5, 46-51. [CrossRef]

45. Mkuna, E.; Mugula, V.J. Farmer's Perceptions on Climate Change Impacts in Different Rice Production Systems in Morogoro Tanzania. Int. J. Sci. Res. 2016, 6, 334-340.

46. Abdul-Gafar, A.; Xu, S.; Yu, W. Perceptions of Rice Farmers towards Production Constraints: Case Study of Niger State of Nigeria and Hainan of China. J. Agric. Chem. Environ. 2016, 5, 20-30. [CrossRef]

47. Ayeyarwady Regional Office. Regional Record of 2016-17; Department of Agriculture: Nay Pyi Taw, Myanmar, 2017.

48. Paing Oo, S. Farmers' Awareness of the Low Yield of Conventional Rice Production in Ayeyarwady Region, Myanmar: A Case Study of Myaungmya District. Agriculture 2020, 10, 26. [CrossRef]

49. Eric, G.O.; Lagat, J.K.; Ithinji, G.K.; Mutai, B.K.; Kenneth, S.W.; Joseph, M.K. Maize Farmers' Perceptions towards Organic Soil Management Practices in Bungoma Country, Kenya. Res. J. Environ. Earth Sci. 2013, 5, 41-48. [CrossRef] 
50. Hayran, S.; Gul, A.; Saridas, M.A. Farmers' Sustainable Agriculture Perception in Turkey: The Case of Mersin Province. New Medit 2018, 3, 69-78. [CrossRef]

51. Hosseini, S.J.F.; Mohammadi, F.; Mirdamadi, S.M. Factors Influencing the Economic Aspects of Sustainable Agriculture in Iran. Arch. Appl. Sci. Res. 2011, 3, 503-512.

52. Shahpasand, M.R. Relationship between Awareness of Sustainable Agriculture and Fertilizer Usage by Iranian Farmers in the City of Bajestan in Khorasan Province: A Case Study. J. Agric. Sustain. 2014, 5, 104-124.

53. Bagheri, A. Potato Farmers' Perceptions of Sustainable Agriculture: The Case of Ardabil Province of Iran. Procedia Soc. Behav. Sci. 2010, 5, 1977-1981. [CrossRef]

54. Acheampong, P.P.; Amengor, N.E.; Nimo-Wiredu, A.; Adogoba, D.; Frimpong, B.N.; Haleegoah, J.; AduAppiah, A. Does Awareness Influence the Adoption of Agricultural Technologies? The Case of Improved Sweet Potato Varieties in Ghana. In Proceedings of the 2nd GAAE Conference, Kumasi, Ghana, 9-11 August 2018.

55. Mustafa, G.; Latif, I.A.; Bashir, M.K.; Shamsudin, M.N.; Daud, W.M.N.W. Determinants of Farmers' Awareness of Climate Change. Appl. Environ. Educ. Commun. 2019, 18, 219-233. [CrossRef]

56. Gujarati, D. Econometrics by Example; Palgrave Mcmilan: New York, NY, USA, 2012.

57. Uddin, M.N.; Bokelmann, W.; Dunn, E.S. Determinants of Farmers' Perception of Climate Change: A Case Study from the Coastal Region of Bangladesh. Am. J. Clim. Chang. 2017, 6, 151-165. [CrossRef]

58. Allahyari, M.S.; Chizari, M.; Homaee, M. Perceptions of Iranian Agricultural Extension Professionals toward Sustainable Agriculture Concepts. J. Agric. Soc. Sci. 2008, 4, 101-106.

(C) 2020 by the authors. Licensee MDPI, Basel, Switzerland. This article is an open access article distributed under the terms and conditions of the Creative Commons Attribution (CC BY) license (http://creativecommons.org/licenses/by/4.0/). 